\title{
PERTUMBUHAN DAN HASIL DUA JENIS TANAMAN TERUNG (Solanum melongena L.) DENGAN PENGAPLIKASIAN BEBERAPA JENIS PUPUK KOTORAN HEWAN
}

\author{
(Growth and Yield of Two Types Eggplant ( Solanum melongena L.) With Application Several \\ Types of Animal Manure)
}

Taufik Hidayat, Susylowati, Alvera Prihatini Dwi Nazari

Jurusan Agroekoteknologi, Fakultas Pertanian, Universitas Mulawarman

Jalan Pasir Balengkong, Kampus Gunung Kelua, Samarinda 75119, Kalimantan Timur, Indonesia.

Coresponden author : susy_rusdi2@yahoo.com

Article Submitted : 01-08-2019

Article Accepted : :03-10-2019

\begin{abstract}
Eggplant (Solanum melongena L.) is one of plant that has potential to be cultivated. Application of animal manure (cow, goat, chicken and swallow) are expected to be able to increase the growth and yield of eggplant. This research was carried out to know: (1) interaction between types of eggplant and animal manure, (2) response of two types of eggplant on the types of animal manure, (3) the effect of types of manure on two types of eggplant. The experiment was conducted for five months, from June to November 2018, in Lempake Dalam, Samarinda Ilir, Samarinda. This research was a $2 \times 4$ factorial experiment that arranged in Randomized Complete Block Design (RCBD) with four replication. The first factor was type of eggplant, consisted of purple eggplant and green eggplant. The second factor was type of animal manure, consisted of cow manure, goat manure, chicken manure, and swallow dung. The data obtained were analyzed by analysis of variance and if the treatment effect has significantly different, to compare between two treatment averages, continued by the Least Significant Different (LSD) test on level at 5\%. The statistical analysis showed that had no interactions between type of eggplant and animal manure on the growth and yield of eggplant. The type of eggplant showed significantly different on the increment of plant height at 45 days after transplanting and fruit diameter and highly significant different on the fresh weight fruit per plant, fresh weight of fruit per plot highly significant and fresh weight of fruit per ha. The green eggplant had higher fresh fruit weight, it was $19.10 \mathrm{Mg} \mathrm{ha}^{-1}$. The animal manure had significantly different on the increment of plant height at 45 days after transplanting and fresh fruit weight per plant. Swallow dung had better effect on the growth and yield of eggplant with highest fresh fruit weight, it was $0.85 \mathrm{~kg} \mathrm{plant}^{-1}$.
\end{abstract}

Keywords : Animal Manure, Eggplant, Growth, Yield

\section{PENDAHULUAN}

Terung (Solanum melongena L.) adalah tanaman pangan yang mudah dibudidayakan dan murah harganya yang ditanam untuk dimanfaatkan buahnya. Tanaman terung mengandung beberapa zat gizi seperti: vitamin $\mathrm{A}$, vitamin $\mathrm{B}$, vitamin $\mathrm{C}$, kalium, fosfor, zat besi, protein, lemak, dan karbohidrat. Keunggulan tersebut menjadikan komoditas terung sangat potensial untuk dikembangkan secara intensif dalam skala agribisnis sekaligus penyumbang cukup besar terhadap keanekaragaman bahan pangan bergizi bagi penduduk (Rukmana, 2006). 
Menurut Badan Pusat Statistik (2013), produktivitas tanaman terung di Indonesia mengalami kenaikan sebesar $1,43 \%$ sejak tahun 1997 sampai tahun 2012 menjadi $518.827 \mathrm{Mg} \mathrm{ha}^{-1}$. Meskipun produksi terung nasional tiap tahun cenderung meningkat, namun produksi terung di Indonesia masih rendah dan hanya menyumbang $1 \%$ dari kebutuhan dunia (Simatupang, 2010).

Peningkatan produksi terung dapat dilakukan diantaranya melalui usaha peningkatan produktivitas dan efisiensi penggunaan tanah, yaitu dengan pemupukan. Pemupukan merupakan usaha memberikan tambahan nutrisi dan unsur hara baik makro maupun mikro dengan tujuan mendapatkan pertumbuhan dan perkembangan yang lebih baik. Jenis pupuk berdasarkan bahan bakunya terdiri atas pupuk anorganik dan pupuk organik (Novizan, 2005).

Pupuk organik merupakan pupuk yang berasal dari sisa tanaman, hewan atau manusia yang telah mengalami proses dekomposisi oleh mikroorganisme, sehingga secara keseluruhan pupuk organik dapat memperbaiki sifat kimia, fisik dan biologi tanah. Pupuk organik dapat memperbaiki degradasi lahan, terutama kekurangn unsur karbon. Perombakan bahan organik dari pupuk organik dapat mengembalikan unsur hara tanah yang berperan menyediakan hara bagi tanaman untuk mendapatkan produktivitas yang optimal (Sutedjo, 2002).

Jenis-jenis pupuk organik dibedakan dari bahan baku, metode pembuatan dan wujudnya. Dari sisi bahan baku, ada yang terbuat dari pupuk kotoran, hijauan atau campuran keduanya (Novizan, 2005).

Pupuk kotoran hewan kaya akan nitrogen dan mineral logam, seperti magnesium, kalium, dan kalsium. Namun demikian, manfaat utama pupuk kotoran adalah mempertahankan struktur fisik tanah sehingga akar dapat tumbuh secara baik (Mayadewi, 2007).

Pupuk kotoran hewan adalah salah satu pupuk organik yang memiliki kandungan hara yang dapat mendukung kesuburan tanah dan pertumbuhan mikroorganisme dalam tanah. Pemberian pupuk kotoran sapi, pupuk kotoran kambing, pupuk kotoran ayam dan pupuk kotoran walet dapat menambah tersedianya unsur hara juga dapat mendukung pertumbuhan mikroorganisme serta mampu memperbaiki struktur tanah. Pupuk kotoran hewan memiliki sifat yang alami dan tidak merusak tanah dan juga menyediakan unsur hara makro (nitrogen, fosfor, kalium) serta unsur mikro (besi, seng, boron, kobalt, dan molibdenum) (Mayadewi, 2007). Penelitian ini bertujuan untuk mengetahui interaksi, respon dan pengaruh pupuk kotoran hewan terhadap kedua jenis tanaman terung.

Tujuan penelitian adalah untuk mengetahui : (1) interaksi antara jenis tanaman terung dengan pupuk kotoran hewan; (2) respon dua jenis tanaman terung terhadap jenis pupuk kotoran hewan dan (3) pengaruh jenis pupuk kotoran hewan terhadap dua jenis tanaman terung.

\section{METODE PENELITIAN}

\section{Waktu dan Tempat}

Penelitian dilaksanakan di Desa Lempake Dalam, Kecamatan Samarinda Ilir, Kota Samarinda dari bulan Juni sampai dengan November 2018.

\section{Bahan dan Alat}

Bahan yang digunakan dalam penelitian ini terdiri atas: benih tanaman terung ungu dan terung hijau, polybag berukuran $8 \mathrm{~cm} \times 9 \mathrm{~cm}$, kompos, sekam, tanah, pupuk kotoran hewan: sapi, kambing, ayam dan walet, dan pestisida nabati.

Alat yang digunakan dalam penelitian ini adalah timbangan analitik, cangkul, parang, peralatan tulis menulis, kamera, penggaris, meteran dan gembor.

\section{Rancangan Percobaan}

Penelitian ini merupakan percobaan faktorial $2 \times 4$ disusun dalam Rancangan Acak Kelompok (RAK) dengan empat ulangan. Faktor I adalah jenis tanaman terung (T) terdiri atas: $\mathrm{t}_{1}=$ terung ungu; dan $\mathrm{t}_{2}=$ terung hijau. Faktor II adalah jenis pupuk kotoran hewan (P), 
yang terdiri atas 4 taraf yaitu: $\mathrm{p}_{1}=$ pupuk kotoran sapi $\mathrm{p}_{2}=$ pupuk kotoran kambing; $\mathrm{p}_{3}=$ pupuk kotoran ayam; dan $\mathrm{p}_{4}=$ pupuk kotoran walet.

\section{Prosedur Penelitian}

\section{Persiapan benih}

Benih yang digunakan untuk budidaya terung memiliki daya tumbuh diatas $75 \%$ sehingga kebutuhan benih untuk satu hektar mencapai 300-500 g. Sebelum ditanam di lahan terbuka, benih terung disemaikan terlebih dahulu. Persemaian menggunakan polybag berukuran $8 \mathrm{~cm} \times 9 \mathrm{~cm}$ yang diisi dengan campuran tanah, kompos dan sekam dengan perbandingan 1:1:1. Polybag persemaian diletakkan di tempat yang teduh serta tidak terkena sinar matahari langsung.

Benih terung direndam dalam air hangat selama 10-15 menit, kemudian benih dibungkus dengan kain basah dan didiamkan selama 24 jam. Benih yang telah diperlakukan ditanam sebanyak dua benih per polybag. Setelah ditanam, dilakukan penyiraman setiap hari sampai tanaman berumur 25 hari dan telah memiliki minimal 4 helai daun, tanaman tersebut dipindahkan ke bedengan yang telah disiapkan.

\section{Persiapan bedengan}

Lahan dibersihkan dari gulma, kemudian dicangkul sampai gembur dan dibagi menjadi empat kelompok, setiap kelompok terdiri atas delapan petak masing-masing petak berukuran $280 \mathrm{~cm} \times 240 \mathrm{~cm}$ dengan jarak antar petak 50 $\mathrm{cm}$ dan jarak antar bedengan $1 \mathrm{~m}$. Pembuatan bedengan dilakukan satu bulan sebelum penanaman, setelah itu pada bedengan dibuat lubang tanam dengan kedalaman $15-20 \mathrm{~cm}$ dan jarak tanam $70 \mathrm{~cm} \times 60 \mathrm{~cm}$.

\section{Pemberian perlakuan}

Perlakuan pupuk kotoran hewan diberikan dua minggu sebelum tanam dengan dosis untuk masing-masing sebanyak $1,05 \mathrm{~kg}$ lubang tanam ${ }^{-1}$.

Penanaman dilakukan pada bibit yang telah berumur 25 hari ditanam dalam lubang tanam yang telah disiapkan sebanyak satu bibit per lubang. Bibit yang dipakai telah diseleksi terlebih dahulu, yaitu dipilih bibit yang sehat dan bebas dari hama dan penyakit serta pertumbuhannya seragam.

4. Pemeliharaan tanaman meliputi:

a. Penyiraman dilakukan setiap pagi dan sore hari atau disesuaikan dengan kondisi kelembaban tanah dan cuaca.

b. Penyulaman dilakukan pada minggu pertama setelah penanaman pada tanaman yang mati, terserang hama dan penyakit, serta pertumbuhannya yang kurang baik. Bibit yang mati dicabut dan langsung diganti dengan bibit yang sudah tersedia.

c. Penyiangan dilakukan setiap minggu atau menyesuaikan dengan keadaaan lahan. Penyiangan adalah dengan membersihkan gulma atau tanaman lain yang tumbuh di sekitar tanaman dengan cara dicangkul atau dicabut secara manual, dilakukan dengan berhati-hati agar tidak merusak atau mengganggu pertumbuhan tanaman.

d. Pengendalian hama dan penyakit

Hama yang sering ditemui adalah bekicot, belalang dan lain-lain. Hama dikendalikan secara hayati, yaitu dipungut atau disemprot dengan pestisida nabati. Pestisida nabati yang digunakan yaitu air rebusan daun sirsak dengan konsentrasi 1 L pestisida nabati dicampur dengan air sebanyak 10-15 $\mathrm{L}$, disemprotkan pagi hari jika tanaman mulai terserang hama, penyemprotan dilakukan pada tanaman yang terserang hama saat tanaman berumur 20 HSPT.

Cara pembuatan pestisida nabati daun sirsak: Daun sirsak ditumbuk sebanyak 100 lembar hingg halus dan rendam dalam lima liter air dan ditambahkan 15 gram ditergen diamkan sehari semalam, kemudian saring larutan dengan kain bersih.

Cara pengaplikasian pestisida nabati: Larutkan satu liter pestisida nabati kedalam 10 liter air bersih untuk disemprotkan ke tanaman yang terserang hama.

e. Panen

Pemanenan dilakukan pertama kali saat tanaman berumur 45 Hari Setelah Pindah Tanam (HSPT) dengan ciri-ciri fisik, yaitu 
memiliki warna buah yang mengkilat, daging buah belum terlalu keras dan ukuran buah sedang, tidak terlalu besar. Waktu panen sore hari dengan cara buah dipetik dengan tangkainya. Panen dilakukan sebanyak tiga kali.

\section{Pengambilan Data}

1. Pertambahan tinggi tanaman $(\mathrm{cm})$

Pertambahan tinggi tanaman diukur menggunakan meteran dari batang di atas permukaan tanah sampai titik tumbuh pada saat tanaman berumur 45 dan 65 HSPT. Pertambahan tinggi tanaman diperoleh dengan cara data hasil pengukuran tinggi tanaman saat pengamatan dikurangi tinggi tananam hasil pengukuran pada saat tanam sebelumnya pada tanaman sampel yang telah ditentukan.

2. Jumlah cabang (buah) dihitung pada saat panen pada tanaman sampel yang telah ditentukan.

3. Jumlah Buah per Tanaman (buah)

Pengambilan data dilakukan dengan cara menghitung jumlah buah yang dihasilkan per tanaman dalam petak hasil dari panen pertama sampai panen terakhir.

4. Diameter Buah (cm)
Diameter buah diukur dengan menggunakan jangka sorong pada buah yang dipanen dari panen pertama sampai panen terakhir di setiap petak hasil kemudian dirata-ratakan.

5. Panjang Buah $(\mathrm{cm})$

Pengambilan data dilakukan setelah panen dengan mengukur panjang buah dari pangkal sampai ke ujung buah menggunakan penggaris pada semua buah yang dipanen kemudian dirata-ratakan.

6. Berat Segar Buah per Tanaman $(\mathrm{kg})$

Pengambilan data dilakukan segera setelah panen pada tanaman dengan cara menimbang seluruh buah dari panen pertama sampai panen terakhir pada tanaman dari petak hasil dengan menggunakan timbangan analitik, hasil dari penimbangan kemudian dirataratakan.

7. Berat Segar Buah per Petak $(\mathrm{kg})$

Data berat segar buah per petak diperoleh dengan cara menimbang seluruh buah dari petak hasil dengan menggunakan timbangan analitik. Berat segar buah per petak lalu di tambahkan dari panen pertama sampai panen terakhir.

8. Berat Segar Buah per hektar $\left(\mathrm{Mg}\right.$ ha $\left.^{-1}\right)$ Berat segar buah per Hektar dihitung dengan Rumus sebagai berikut:

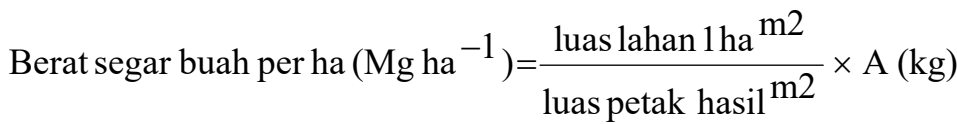

Keterangan:

- Luas petak hasil $=140 \mathrm{~cm} \times 120 \mathrm{~cm}$

- $\mathrm{A}=$ berat segar buah per petak $\left(\mathrm{kg} \mathrm{m}^{-2}\right)$

- Luas lahan $1 \mathrm{ha}=10.000 \mathrm{~m}^{2}$

\section{HASIL DAN PEMBAHASAN}

Hasil penelitian pertumbuhan dan hasil dua jenis tanaman terung (Solanum melongena L.) dengan pengaplikasian beberapa jenis pupuk kotoran hewan disajikan pada Tabel 1. 
Tabel 1. Hasil Penelitian Pertumbuhan dan Hasil Dua Jenis Tanaman Terung dengan Aplikasi Beberapa Jenis Pupuk Kotoran Hewan

\begin{tabular}{|c|c|c|c|c|c|c|c|c|c|}
\hline \multirow{3}{*}{ Faktor } & \multicolumn{9}{|c|}{ Variabel yang diamati } \\
\hline & \multicolumn{2}{|c|}{$\begin{array}{c}\text { Pertambahan } \\
\text { Tinggi Tanaman } \\
\text { (cm) }\end{array}$} & \multirow{2}{*}{$\begin{array}{c}\text { Jumlah Cabang } \\
\text { (buah) }\end{array}$} & \multirow{2}{*}{$\begin{array}{c}\text { Diameter Buah } \\
\text { (cm) }\end{array}$} & \multirow{2}{*}{$\begin{array}{c}\text { Panjang Buah } \\
\text { (cm) }\end{array}$} & \multirow{2}{*}{$\begin{array}{c}\text { Jumlah } \\
\text { Buah }\end{array}$} & \multicolumn{3}{|c|}{ Berat Segar Buah } \\
\hline & $\begin{array}{c}45 \\
\text { HSPT }\end{array}$ & $\begin{array}{c}65 \\
\text { HSPT }\end{array}$ & & & & & $\begin{array}{c}\text { Per } \\
\text { Tanaman } \\
(\mathrm{kg})\end{array}$ & $\begin{array}{c}\text { Per } \\
\text { Petak } \\
\text { (kg) }\end{array}$ & $\begin{array}{r}\text { Per ha } \\
\text { (Mg) }\end{array}$ \\
\hline Jenis Tanaman Terung ( $\mathrm{T}$ ) & $*$ & tn & tn & * & tn & $* *$ & $* *$ & $* *$ & \\
\hline $\mathrm{t}_{1}=$ ungu & $6,72 \mathrm{a}$ & 12,08 & 9,34 & $9,96 \mathrm{a}$ & 17,13 & 5,19 & $0,54 \mathrm{a}$ & $2,25 \mathrm{a}$ & $12,56 \mathrm{a}$ \\
\hline $\mathrm{t}_{2}=$ Hijau & $8,49 \mathrm{~b}$ & 11,99 & 8,46 & $11,71 \mathrm{~b}$ & 18,30 & 6,23 & $0,82 \mathrm{~b}$ & $3,20 \mathrm{~b}$ & $19,10 \mathrm{~b}$ \\
\hline BNT T & 1,50 & - & - & 1,38 & - & - & 0,14 & 0,63 & 3,76 \\
\hline Jenis Pupuk Kotoran Hewan (P) & $*$ & tn & tn & tn & tn & tn & * & tn & tn \\
\hline $\mathrm{p}_{1}=$ Sapi & $7,86 a b$ & 12,20 & 8,31 & 9,46 & 16,41 & 5,54 & $0,59 \mathrm{a}$ & 2,36 & 14,03 \\
\hline $\mathrm{p}_{2}=$ Kambing & $5,94 \mathrm{a}$ & 13,75 & 9,15 & 11,15 & 18,08 & 4,94 & $0,57 \mathrm{a}$ & 2,14 & 12,77 \\
\hline $\mathrm{p}_{3}=$ Ayam & $9,07 \mathrm{~b}$ & 11,39 & 8,14 & 11,05 & 17,92 & 6,31 & $0,71 \mathrm{ab}$ & 2,85 & 16,97 \\
\hline $\mathrm{p}_{4}=$ Walet & $7,56 \mathrm{ab}$ & 10,81 & 10,01 & 11,67 & 18,44 & 6,06 & $0,85 \mathrm{~b}$ & 3,28 & 19,56 \\
\hline BNT P & 2,12 & - & - & - & - & - & 0,20 & - & - \\
\hline Interaksi (TxP) & tn & tn & tn & tn & tn & tn & tn & tn & tn \\
\hline Ungu x Sapi & 6,27 & 13,41 & 10,38 & 7,74 & 14,20 & 3,96 & 0,38 & 1,52 & 9,04 \\
\hline Ungu x Kambing & 6,34 & 14,89 & 8,88 & 10,74 & 18,58 & 5,44 & 0,57 & 2,27 & 13,52 \\
\hline Ungu x Ayam & 7,03 & 12,37 & 6,71 & 10,24 & 18,15 & 5,94 & 0,58 & 2,31 & 13,78 \\
\hline Ungu $\mathrm{x}$ Walet & 7,24 & 7,65 & 11,40 & 11,12 & 17,61 & 5,44 & 0,65 & 2,34 & 13,92 \\
\hline Hijau x Sapi & 9,45 & 10,99 & 6,25 & 11,18 & 18,63 & 7,13 & 0,80 & 3,19 & 19,02 \\
\hline Hijau x Kambing & 5,54 & 12,61 & 9,42 & 11,56 & 17,58 & 4,44 & 0,58 & 2,01 & 12,01 \\
\hline Hijau x Ayam & 11,12 & 10,40 & 9,56 & 11,86 & 17,69 & 6,69 & 0,85 & 3,39 & 20,17 \\
\hline Hijau x Walet & 7,87 & 13,97 & 8,63 & 12,22 & 19,28 & 6,69 & 1,06 & 4,23 & 25,20 \\
\hline
\end{tabular}

\section{Pertumbuhan dan Hasil Dua Jenis Tanaman Terung}

Berdasarkan hasil sidik ragam penelitian menunjukkan bahwa jenis tanaman terung memberikan pengaruh yang nyata terhadap lima variabel pertumbuhan diantaranya pertambahan tinggi tanaman umur 45 HSPT, diameter buah, berat segar buah per tanaman, per petak dan per hektar, sedangkan pada jumlah cabang, panjang buah dan jumlah buah memberikan pengaruh yang tidak nyata. Hasil penelitian yang disajikan pada Tabel 1 menunjukkan bahwa jenis terung hijau $\left(\mathrm{t}_{2}\right)$ memberikan pengaruh yang lebih baik terhadap beberapa variabel penelitian dibandingkan terung ungu $\left(\mathrm{t}_{1}\right)$. Perbedaan pertumbuhan dan hasil antara antara terung hijau dan terung ungu diduga dipengaruhi oleh faktor genetik yang berbeda antar kedua jenis terung yang sebagaimana ditunjukkan oleh deskripsi berdasarkan surat keputusan Menteri Pertanian No.58/Kpts/TP.120/7/2008 dan 4717/Kpts/TP.120/7/2011) yang mengungkapkan bahwa terung hijau varietas 211 memang memiliki pertumbuhan yang lebih tinggi dari pada terung ungu varietas 2405. Jenis terung hijau ( $\left.t_{2}\right)$ memberikan berat segar buah yang lebih tinggi, yaitu $19,10 \mathrm{Mg}$ $\mathrm{ha}^{-1}$, dibandingkan dengan terung ungu sebesar $12,56 \mathrm{Mg} \mathrm{ha}^{-1}$.

Hasil penelitian tersebut sesuai dengan hasil penelitian yang dilaporkan oleh Sriyanto, dkk. (2015) bahwa jenis terung hijau cenderung memiliki pertumbuhan yang lebih baik dibandingkan terung ungu, terutama pada tinggi tanaman, diameter buah dan berat buah terung. Selanjutnya dinyatakan oleh Sabatino (2013) bahwa dalam penelitiannya 
tanaman terung hijau memiliki kemampuan lebih baik dalam menyerap nutrisi di dalam tanah sehingga dapat tumbuh lebih cepat dibandingkan jenis varietas terung lainnya, hal tersebut dibuktikan dengan tingginya pertumbuhan, perkembangan dan hasil panen tanaman terung hijau.

Selain itu hasil penelitian oleh Aied, et al. (2017) yang melakukan uji kimia menunjukkan bahwa terung hijau memiliki kandungan protein dan beberapa makronutrient seperti kalium, kalsium, serta senyawa mikronutrient seperti $\mathrm{Fe}, \mathrm{Zn}$ dan $\mathrm{Cu}$ yang tinggi. Fenomena tersebut mungkin disebabkan oleh fakta bahwa tanaman terung hijau mampu mengambil nutrisi dan air yang lebih besar dibandingkan terung ungu selama tahap awal siklus biologis, yang akan digunakan untuk aktivitas pertumbuhan tanaman, dan fase reproduksi yang pada akhirnya menghasilkan kualitas buah yang lebih baik. Hasil penelitian tersebut sejalan dengan hasil penelitian ini yang menunjukkan bahwa pertumbuhan tinggi tanaman dan hasil tanaman terung hijau lebih baik dibandingkan terung ungu. Perbedaan kemampuan fisiologis dan karakter morfologis dari kedua jenis tanaman terung tersebut diduga disebabkan pengaruh faktor genetik yang berbeda. Menurut Cericola, et al., (2013), varietas terung secara morfologis, fisiologis dan biokimia memang sangat bervariasi, sehingga akan menghasilkan pertumbuhan dan perkembangan yang berbeda pula.

Pertumbuhan dan Hasil Tanaman Terung Dengan Pengaplikasian Beberapa Jenis Pupuk Kotoran Hewan

Pupuk organik yang berasal dari kotoran hewan memiliki kemampuan untuk meningkatkan produktivitas hasil pertanian di Indonesia. Kotoran hewan dapat membantu meningkatkan jumlah atau populasi mikroorganisme tanah yang berpengaruh dalam melindungi tanaman terhadap patogen seperti nematoda dan serangga, serta menyediakan hormon pertumbuhan tanaman misalnya auksin (Agbede and Ojeniyi, 2009).
Penelitian ini menggunakan pupuk organik dari beberapa jenis kotoran hewan yaitu sapi, kambing, ayam dan walet.

Hasil sidik ragam menunjukkan bahwa perlakuan jenis pupuk kotoran hewan memberikan pengaruh yang nyata terhadap dua variabel pertumbuhan kedua jenis tanaman terung, yaitu pertambahan tinggi tanaman pada umur 45 HSPT dan berat segar buah per tanaman, sedangkan pada variabel lain (pertambahan tinggi tanaman pada umur 65 HSTP, jumlah cabang, diameter buah, panjang buah, jumlah buah, berat segar buah per petak, dan berat segar buah per hektar) pengaruhnya tidak nyata. Hasil penelitian yang disajikan pada Tabel 1 menunjukkan bahwa jenis pupuk kotoran ayam dan walet cenderung memberikan pengaruh yang lebih baik terhadap pertumbuhan dan hasil tanaman terung $\backslash$ dibandingkan dengan pupuk kotoran sapi $\left(\mathrm{p}_{1}\right)$ dan kambing $\left(\mathrm{p}_{2}\right)$, walaupun hasil sidik ragam menunjukkan bahwa pengaruh jenis pupuk kotoran hewan berpengaruh tidak nyata untuk semua variabel yang diamati, kecuali pada variabel pertambahan tinggi tanaman pada umur 45 HSPT dan berat segar buah per tanaman.

Hasil penelitian ini didukung oleh hasil penelitian Usman (2015) bahwa pupuk kotoran ayam memiliki pengaruh yang paling baik untuk meningkatkan tinggi tanaman tomat dibandingkan dengan pupuk kotoran sapi dan kambing. Dilaporkan oleh Andayani dan Sarido (2013) bahwa pupuk kotoran ayam dapat meningkatkan pertumbuhan dan perkembangan tanaman cabai keriting dibandingkan pupuk kotoran sapi dan kambing. Pupuk kotoran ayam diketahui dapat memasok nutrisi yang cukup ke tanah, sehingga dapat mempercepat pertumbuhan vegetatif dan generatif tanaman (Aiyelaagbe, et al., 2005; Katung, et al., 2005).

Gbenou, et al. mengungkapkan bahwa pupuk kotoran unggas seperti ayam dan burung walet memiliki kandungan makronutrien seperti NPK (nitrogen, fosfat dan kalium) yang lebih tinggi 
dibandingkan dengan pupuk dari kotoran hewan lainnya. Hasil penelitian Gbenou, et al. (2017), menunjukkan bahwa kotoran unggas mengandung $\mathrm{N}$ sebesar $11,7 \mathrm{~g} \mathrm{~kg}^{-1}, \mathrm{P}$ sebesar 4,6 $\mathrm{g} \mathrm{kg}^{-1}$ dan $\mathrm{K}$ sebesar 7,6 $\mathrm{g} \mathrm{kg}^{-1}$, sedangkan kotoran kambing mengandung $\mathrm{N}$ sebesar $6,0 \mathrm{~g}$ $\mathrm{kg}^{-1}$, P sebesar 4,9 $\mathrm{g} \mathrm{kg}^{-1}$ dan $\mathrm{K}$ sebesar 7,3 $\mathrm{g}$ $\mathrm{kg}^{-1}$.

Kotoran unggas diantaranya ayam dan walet, memiliki kandungan nitrogen $(\mathrm{N})$ yang lebih tinggi serta nutrisi lain yang secara bertahap dilepaskan ke tanaman ( Awodun, 2007 dan Khalil, et al., 2005). Nitrogen yang berasal dari pupuk kotoran ayam dan walet dapat merangsang pertumbuhan tanaman (Anyaegbu et al., 2010). Pertumbuhan yang lebih baik pada tanaman yang diberi perlakuan pupuk ayam dan walet, dikaitkan dengan rasio $\mathrm{C} / \mathrm{N}$ yang lebih rendah (Maerere, et al., 2001). Hasil penelitian ini menunjukkan terjadi peningkatan pertambahan tinggi tanaman pada perlakuan pupuk kotoran ayam, dan perlakuan pupuk kotoran walet pada berat segar buah per tanaman (Tabel 1). Proses dekomposisi pupuk kotoran ayam dan walet berjalan lebih cepat daripada kotoran sapi dan kambing, sehingga unsur-unsur hara N, P dan $\mathrm{K}$ yang diperlukan tanaman yang diberi pupuk kotoran ayam dan walet lebih cepat tersedia dalam tanah, sehingga proses pertumbuhan dan perkembangannya jauh lebih cepat (Diaz, et al., 2008). Walaupun hasil penelitian ini menunjukkan bahwa pengaruh pupuk kotoran berpengaruh tidak nyata terhadap sebagian besar variabel pengamatan, tetapi pupuk kotoran walet dan ayam memberikan pengaruh yang cenderung lebih baik terhadap pertumbuhan dan hasil tanaman terung.

Terung sangat responsif terhadap pupuk N. Defisiensi dan kelebihan N akan mengurangi potensi produksi terung. Untuk menghasilkan $1 \mathrm{Mg}$ terung segar, dibutuhkan 3-3,5 kg nitrogen (Sharma and Brar, 2008). Nafiu, et al. (2011), menjelaskan bahwa terung memiliki potensi waktu panen yang lebih lama, sehingga dibutuhkan pupuk $\mathrm{N}$ yang cukup selama pertumbuhan. Berdasarkan fakta tersebut dapat dikatakan bahwa tanaman terung yang diberi pupuk kotoran ayam dan walet tumbuh lebih baik dibandingkan tanaman terung yang diberi pupuk kotoran sapi dan kambing. Hal tersebut disebabkan pupuk kotoran ayam dan walet mampu meningkatkan ketersediaan $\mathrm{N}$ dan $\mathrm{P}$ pada tanah, sehingga dapat meningkatkan tinggi tanaman dan berat buah segar per tanaman.

Perbedaan respons tanaman sebagian besar bisa disebabkan oleh perbedaan total N, total $\mathrm{P}$ dan karbon organik dari keempat jenis kotoran hewan. Kotoran unggas memiliki tingkat total $\mathrm{N}$ tertinggi, total $\mathrm{P}$ dan rasio tersempit dari $\mathrm{C} / \mathrm{N}$ dan $\mathrm{C} / \mathrm{P}$, menunjukkan mineralisasi superior (Maerere, et al., 2001).

Kotoran sapi dan kambing memiliki kandungan nitrogen yang tidak tinggi, dan tidak memiliki dampak secara langsung seperti pupuk kimia, serta melepaskan nutrisi dalam jangka waktu yang lebih lama dibandingkan pupuk kotoran ayam dan walet (Gbenou, et al., 2017). Pupuk kotoran sapi dan kambing mengandung berbagai jenis serat organik yang berasal dari pakan tumbuh-tumbuhan pada hewan ternak yang menyebabkan proses dekomposisi bahan organiknya berlangsung lebih lambat dibandingkan pupuk kotoran ayam dan walet (Jamilah, 2002). Walaupun begitu, kotoran sapi dan kambing diketahui terdiri dari tiga elemen dasar yang penting bagi kesehatan tanaman, yaitu nitrogen, fosfor dan kalium.

Pupuk kotoran sapi dan kambing juga mengandung bakteri pengurai selulosa dan enzim pencernaan aktif yang berkontribusi pada proses metabolisme yang mampu mempercepat penguraian bahan organik oleh mikroorganisme tanah yang diduga merupakan faktor-faktor yang menyebabkan pertumbuhan tanaman terung dari segi pertumbuhan lain, seperti jumlah cabang, diameter buah, jumlah buah, panjang buah dan berat segar buah per petak maupun berat segar per hektar yang diberi pupuk kotoran sapi dan kambing menunjukkan pengaruh tidak nyata dengan 
pertumbuhan tanaman terung yang diberi pupuk kotoran ayam dan walet.

Penggunaan pupuk organik dari kotoran hewan pada dasarnya mampu meningkatkan pertumbuhan dan hasil produksi tanaman, mungkin disebabkan oleh fakta bahwa pupuk organik kotoran hewan dapat menyediakan bahan gizi mikro seperti $\mathrm{Zn}, \mathrm{Cu}, \mathrm{Fe}, \mathrm{Mn}$ dan $\mathrm{Mg}$ pada tingkat optimal. Penerapan pupuk organik kotoran hewan dengan demikian akan membantu dalam aktivitas metabolisme tanaman melalui pasokan mikronutrien yang penting dalam pertumbuhan awal yang kuat (Anburani dan Manivannan, 2002).

\section{Interaksi antara Jenis Terung dan Jenis Pupuk Kotoran Hewan}

Berdasarkan hasil sidik ragam menunjukkan bahwa interaksi antara jenis tanaman terung dengan jenis pupuk kotoran hewan memberikan pengaruh yang tidak nyata terhadap semua variabel pengamatan. Keadaan ini dinyatakan oleh Steel dan Torrie (1991) (1991), bahwa apabila pengaruh interaksi berbeda tidak nyata maka disimpulkan bahwa diantara faktor perlakuan tersebut bertindak bebas satu sama lainnya.

Hasil penelitian yang disajikan pada Tabel 1 menunjukkan bahwa pengaruh jenis tanaman terung selalu tetap pada berbagai jenis pupuk kotoran hewan, begitu pula sebaliknya, pengaruh jenis pupuk kotoran hewan selalu tetap pada dua jenis tanaman terung yang digunakan. Hal tersebut diduga karena kedua jenis tanaman terung secara genetik memberikan respon yang sama terhadap pemberian jenis pupuk kotoran hewan yang berbeda (sapi, kambing, ayam dan walet). Hal tersebut sesuai dengan pendapat Suge, et al., (2011) yang mengungkapkan, bahwa apabila tidak terdapat pengaruh yang nyata antara varietas tanaman terung dengan jenis pupuk organik yang digunakan, artinya kedua jenis tanaman terung tersebut memiliki interaksi yang sama dengan semua jenis pupuk kotoran hewan.

\section{KESIMPULAN}

Berdasarkan hasil penelitian yang telah dilaksanakan dapat ditarik kesimpulan sebagai berikut:

1. Tidak terdapat interaksi antara jenis tanaman terung dengan jenis pupuk kotoran hewan terhadap pertumbuhan dan hasil tanaman terung.

2. Jenis tanaman terung menunjukkan respon yang berpengaruh sangat nyata pada variabel berat segar buah per petak, berat segar buah per ha, berat segar buah per tanaman dan berpengaruh nyata pada variabel diameter buah dan tinggi tanaman 45 HSPT. Terung hijau memberikan hasil pada berat buah segar yang tertinggi, yaitu 19,10 Mg.ha-1 .

3. Jenis pupuk kotoran hewan berpengaruh nyata pada variabel berat buah segar per tanaman dan pertambahan tinggi tanaman 45 HSPT. Pupuk kotoran walet memberikan pengaruh yang cenderung lebih baik terhadap pertumbuhan dan hasil tanaman, dan hasil berat buah segar per tanaman yang tertinggi, yaitu $0,85 \mathrm{~kg}$ dan tidak berbeda nyata dengan perlakuan pupuk kotoran ayam, yaitu $0,71 \mathrm{~kg}$.

\section{DAFTAR PUSTAKA}

Aied K.Y., Kamaruddin. R., Wahab. Z., and Shaari. A.R. 2017. Growth response of eggplant (Solanum melongena L.) to shading and sultivation inside greenhouse in a tropical region. International journal of scientific and engineering research. Vol. 8(5): 89101.

Aiyelaagbe, I.O.O., Abiola. I.O., and Sadiku. M.A. 2005. Growth response of juvenile passion fruit (Passiflora edulis f. flavicarpa) to organic and inorganic fertilizers in southwestern nigeria. Nigerian journal of horticultural science. Vol. 10: 18-20. 
Anburani, A. and Manivannan. K. 2002. Effect of integrated nutrient management on growth in brinjal (Solanum melongena L.) cv. Annamalai. South indian horticulture. Vol. 50 (4-6): 377-386.

Andayani and Sarido. L. 2013. Uji empat jenis pupuk kandang terhadap pertumbuhan dan hasil tanaman cabai keriting (Capsicum annum L.). Jurnal AGRIFOR. Vol. 12(1): 22-29.

Anyaegbu, P.O., Iwuanyanwu. U.P., and Ekwughe. E.U. 2010. Nutrient uptake and root yield of cassava as influenced by liming and poultry manure under different cropping system. Int. Sci. Res. J. Vol. 2: 82-89.

Awodun, M.A., 2007. Effect of poultry manure on the growth, yield and nutrient content of fluted pumpkin (Telfaria occidentalis Hook F). Asian J. Agric. Res. Vol. 1: 67-73.

Badan Pusat Statistik., 2013. Produksi tanaman sayur-sayuran menurut jenis production of vegetables by kind. Badan Statistik Provinsi Riau.

Cericola F., Portis. E., Toppino. L., Barchi. L., Acciarri. N., Ciriaci. T. 2013. The population structure and diversity of eggplant from asia and the mediterrania basin. PLOS ONE. Vol. 8(9): 1-16.

Diaz D.A.R., Sawyer. J.E., and Mallarino. A.P. 2008. Poultry manure supply of potentially available nitrogen with soil incubation. Agronomy journal. Vol. 100(5): 1310-1317.

Gbenou, B., Adjolohoun. S., Ahoton. L., Houndjo. D.B.M. 2017. Animal dung availability and their fertilizer values in a context of low soil fertility conditions for forage seed and crops production in benin (West Africa). AJAR. Vol. 2(12): $1-14$.

Jamilah. 2002. Pengaruh pemberian pupuk kandang dan kelengasan terhadap perubahan bahan organik dan nitrogen total entisol. Universitas Sumatera Utara. http://repository.usu.ac.id/bitstream/123456789/113 3/1/Tanah-Jamilah

Katung, M.D., Hussibini. I.M.A., and Olarewaju. J.D. 2005. Yield and storability of onion (Allium cepa) as influenced by organic and inorganic fertilizers in the sudan savannah region of nigeria. Nigerian journal of horticultural science. Vol. 10: 82-86.

Khalil, M.I., Schmidhalter. U., and Gutser. R. 2005. Turnover of chicken manure in some upland soils of Asia: Agricultural and environmental perspective. Proceedings of the international workshop. January 2005, Hamburg, pp: Vol 14: 275-292.

Maerere, A.P., Kimbi. G.C., and Nonga. D.L.M. 2001. Comparative effectiveness of animal manures on soil chemical properties, Yield and Root growth of amaranthus (Amaranthus cruentus L.). Asian J. Sci. Technol. Vol. 1: 14-21.

Mayadewi, N.N.A. 2007. Pengaruh jenis pupuk kandang dan jarak tanam terhadap pertumbuhan gulma dan jagung manis. Agritrop. Vol 4: 153-159

Nafiu, A. K., Togun. A.O., Abiodun. M.O and Chude. V.O. 2011. Effects of NPK fertilizer on growth, drymatter production and yield of eggplant in 
southwestern Nigeria. Agric. Biol. J. N. Am. Vol. 2 (7): 1117-1125

Novizan. 2005. Petunjuk pemupukan yang efektif. Penebar Swadaya, Jakarta.

Rukmana, R. 2006. Bertanam terung. Kanisius, Yogyakarta.

Sabatino, I. 2013. Advances in vegetable grafting and new nursery patterns for grafted plant prodution. Tesis: Universitas Degli Studi di Palermo.

Sharma, S. P and Brar. J.S. 2008. Nutritional requirements of brinjal (Solanum melongena L.) - A review. Agric. Rev. Vol. 29 (2) : $79-88$.

Simatupang, M. 2010. Pengetahuan praktis investasi saham dan dana reksa. Mitra wacana media, Jakarta.

Sriyanto D., Astusti. P., and Sujalu. A.P. 2015. Pengaruh dosis pupuk kandang sapi terhadap pertumbuhan dan hasil tanaman terung ungu dan terung hijau (Solanum melongena L.). Jurnal AGRIFOR. Vol. 14(1): 39-44.

Steel, R.G.D dan J. H. Torrie. 1991. Prinsip dan Prosedur Statistika Suatu Pendekatan Biometrik. Gramedia Pustaka Utama, Jakarta.

Suge, J. K., Omunyin.M.E., and Omami. E.N. 2011. Effect of organic and inorganic sources of fertilizer on growth, yield and fruit quality of eggplant (Solanum melongena L). Arch.Appl.Sci.Res. Vol. 3(6): 470-479

Sutedjo. M. M. 2002. Pupuk dan cara pemupukan. Rineka Cipta. Jakarta.

Usman M. 2015. Cow dung, goat and poultry manure and their effects on the average yields and growth parameters of tomato crop. Journal of biology, agriculture and healthcare. Vol. 5(5):7-10. 